received a B.A. from Oberlin College in 1914, an M.A. from Oberlin in 1915, and a Ph.D. from Columbia University in public law in 1921. His dissertation, Evolution of the Budget in Massachusetts, was informed by his work as the secretary of the Joint Special Commission on the Budget of the Massachusetts General Court, 1916-18. The dissertation was published by MacMillan Company in 1920.

Gulick was president of the Institute of Public Administration in New York City from 1920 to 1962 , and chair of the board from 1962 to 1983. He was appointed Eaton Professor of Municipal Science and Administration by Columbia University in 1931, a position he held until 1942.

His extensive service in and with government included membership with Charles E. Merriam and Louis Brownlow on the President's Committee on Administrative Management, 1935-37. Gulick wrote "Notes on the Theory of Organization" for the Committee and drafted the final report "Administrative Management in the Government of the United States" in 1937. His government service also included positions as consultant to the chief of staff, the War Department, 1941; chief, Bureau of Organization of Planning, the War Production Board, 1941-45; member, the White House staff, 1945-46; member, U.S. Reparations Mission Staff, Moscow, Potsdam, Tokyo, Manila, Paris, Brussels, Nurenberg, and Vienna, 1945-46; executive director, Mayor's Committee on the Management Survey of the City of New York, 1950-53; City Administrator, the City of New York, 1954-56; member, New York City Charter Revision Commission, 1959-61; and member, New York World's Fair Corporation, 1967-72. In various periods he also worked on organization and management problems for the United Nations and the governments of England, Switzerland, France, Germany, Sweden, Italy, Japan, Korea, the Philippines, Greece, Iraq, Taiwan, Iran, India, Egypt, and Peru.

He was active in establishing and governing several professional associations, including the American Society of Public Administration and the National Academy of Public Administration. He was elected president of the American Society of Public Administration in the 1940s and president of the American Political Science Association in 1952.

The computer catalog of the Library of Congress lists 24 volumes under his name. He also published dozens of articles and many reports.

Gulick wrote the "Notes on the Theory of Organization"' as a working document to guide the staff of the President's Commission on Administrative Management. In a discussion of the "Notes" with Lyle Fitch of the Institute of Public Administration, Gulick said he developed his thoughts on a few Sunday afternoons sitting under a tree in the backyard of his Bronxville home.

"I didn't have time to consult any materials; I simply drew out of my subconscious the things I had absorbed while a staff member of the Bureau of Municipal Research" (Lyle Fitch, Making Democracy Work: Luther Gulick, Institute of Governmental Studies, University of California at Berkeley, 1991, p. 32). While he never elaborated on or defended the "Notes" when they were intensely criticized by Herbert Simon and others, many years after their publication he strongly criticized hierarchy as an organizing principle for managing the domestic functions of governments.

Luther Halsey Gulick's legacy is the example of a life of deep intellectual and practical involvement in making democratic institutions work.

James D. Carroll

Florida International University

\section{Richard F. Heiges}

Richard F. Heiges, chair of the political science department at Indiana University of Pennsylvania for 24 years prior to his retirement, passed away on January 23, 1993.

Dick Heiges assumed the chairmanship of the political science department in 1966, at the time when the department was formed out of the Social Science Division. His colleagues regularly reelected him to that post by unanimous votes of approval. Dick's quiet, low-key administrative techniques and his openness and fairness in handling the day-to-day leadership of the department made him one of the most effective chairpersons on the entire campus. The harmonious working relationships which have characterized the department for the past two decades are a direct tribute to his skills.

Among the university administrators, Dick developed the reputation for anticipating bureaucratic deadlines and having his responses on their desks well before the materials were due. His effectiveness in developing well-prepared, carefully considered perspectives on issues meant that he rarely had to provide additional rationales or justifications for his proposals.

Dick Heiges created the internship program at IUP. The program began in the political science department. When its value became obvious, a university-wide internship program was put into place. This program alone has made a lasting and invaluable contribution to the university. Many former IUP interns are now career employees at all levels of government, business, and social service due to the experience they gained from the program. It is undoubtedly Dick's greatest legacy to the university.

Dick's administrative abilities and leadership skills were further recognized when the university decided to create a Center for Community Affairs. Dick was named director of the center at its inception and developed programs for IUP involvement with local and state governments.

Dr. Heiges retired in December of 1990. In the fall of 1992, doctors discovered that Dick had a brain tumor which required immediate surgery. While the operation seemed to be a success, Dick never fully recovered from its after effects. He passed away one day after his sixty-second birthday. The contributions he made to his department, university, and the Indiana community will keep his memory alive for years to come.

Edward E. Platt

Indiana University of Pennsylvania 